\title{
A meta-analysis of baseline characteristics in trials on mite allergen avoidance in asthmatics: room for improvement
}

Frank E. van Boven ${ }^{{ }^{*}}$ (D) Nicolette W. de Jong ${ }^{1}$, Gert-Jan Braunstahl ${ }^{2,3}$, Roy Gerth van Wijk ${ }^{1}$ and Lidia R. Arends ${ }^{4,5}$

\begin{abstract}
Background: Evidence regarding the clinical effectiveness of mite allergen avoidance for the treatment of asthma is lacking. In previous meta-analyses on mite allergen control, the baseline data were not discussed in detail. This study updates and extends the existing Cochrane review by Gøtzsche and Johansen (Cochrane Database of Systematic Reviews, 2008, Art. No: CD001187), with a focus on baseline asthma outcomes and allergen exposures.

Methods: We used the existing trials in the original Cochrane review and included newly published studies. The baseline data for the mite allergen load from the mattress, the standardized asthma symptom score (ASS), the forced expiratory volume in $1 \mathrm{~s}$ percentage of predicted ( $\mathrm{FEV}, \%$ pred.), and the histamine provocative concentration causing a $20 \%$ drop in $\mathrm{FEV}_{1}\left(\mathrm{PC}_{20}\right)$ were extracted. First, the mean values of the outcomes were calculated. The influence of the mite allergen load was examined with a random-effect meta-regression using the Metafor package in $R$.

Results: Forty-five trials were included; 39 trials reported strategies for concurrent bedroom interventions, and 6 trails reported strategies for air purification. The mite allergen load ranged from 0.44 to $24.83 \mu \mathrm{g} / \mathrm{g}$ dust, with a mean of $9.86 \mu \mathrm{g} / \mathrm{g}$ dust $\left(95 \% \mathrm{Cl} 5.66\right.$ to $14.05 \mu \mathrm{g} / \mathrm{g}$ dust, $\left.\mathrm{I}^{2}=99.8 \%\right)$. All health outcomes showed considerable heterogeneity (standardized ASS mean: 0.13, 95\% Cl 0.08 to $0.18, \mathrm{I}^{2}=99.9 \%$; FEV $\%$ pred. mean: $85.3 \%, 95 \% \mathrm{Cl} 80.5$ to $90.1 \%$, $\mathrm{I}^{2}=95.8 \%$; $\mathrm{PC}_{20}$ mean: $1.69 \mathrm{mg} / \mathrm{mL}, 95 \% \mathrm{Cl} 0.86$ to $\left.2.52 \mathrm{mg} / \mathrm{mL}, \mathrm{I}^{2}=95.6 \%\right)$. The covariate mite allergen load did not significantly influence health outcomes.
\end{abstract}

Discussion: This meta-analysis shows that mite avoidance studies are characterized by the inclusion of patients with rather mild to moderate asthma and with varying and sometimes negligible levels of allergen exposure. Future studies should focus on patients with severe asthma and increased levels of allergen exposure.

\section{Introduction}

House dust mite-allergic asthma is a prevalent disorder of the lower airways that affects hundreds of millions of people worldwide $[1,2]$. The immediate allergic reaction to mites [3] suggests that controlling exposure to the antigen could be an appropriate first-line therapy for the treatment of mite-allergic asthma. However, guidelines and reviews provide ambiguous recommendations for mite allergen avoidance [4-6], reflecting a lack of

\footnotetext{
*Correspondence: f.vanboven5@gmail.com

1 Department of Internal Medicine, Section of Allergology \& Clinical Immunology, Erasmus Medical Center, P.O. Box 2040, 3000 CA Rotterdam, The Netherlands

Full list of author information is available at the end of the article
}

consensus in this research field. This lack of consensus on the effectiveness of mite allergen avoidance is summarized by a Cochrane review [7], which was unable to demonstrate any clinical benefit of avoidance measures designed to reduce mite exposure in 55 trials. In addition to the substantial meta-analysis by Gøtzsche and Johansen [7], several other meta-analyses on mite allergen avoidance for the treatment of asthma report varying results for the effectiveness of avoidance [8-11]. The variation in the complex interventions as well as the heterogeneity of several study outcomes urges further exploration $[12,13]$.

The baseline data are a not well reported in the metaanalyses on the effectiveness of mite allergen control. 
These baseline characteristics provide attributes for evidence-based decision making in the daily practice of clinicians [14]. First, in the case of asthma, baseline characteristics are of particular interest because they reflect the level of asthma control and the asthma severity of the patient [15]. Studies still highlight the disparities between the asthma severity results between clinical trials and those reported from patient practice [16]. Treatable traits have been defined in severe asthma patients and may be associated with future exacerbation risk [17]. Second, baseline environmental aspects can influence the treatability of allergen-induced asthma [18]. Third, baseline characteristics provide statistical independence in the asthma outcomes of interest. This quantitative factor relates to the possible relationship between exposure and asthma outcomes; for example, in the paradigm of the bedding site introduced in the 1990s [19]. In such cases, the quantitative evaluation of the clinical effectiveness of the treatment of asthma in a meta-analysis differs from that of the traditional two-sample test [20]. These aspects demonstrate that baseline characteristics in a metaanalysis are important for the interpretation of the study results [21].

This study updates and extends the existing Cochrane review by Gøtzsche and Johansen [7], with a focus on baseline asthma outcomes and allergen exposures.

\section{Methods}

\section{Searches and selections}

The starting point for this protocol was the Cochrane review by Gøtzsche and Johansen [7]. This meta-analysis includes 55 trials. An updating search was performed in the EMBASE, Medline, and Cochrane databases (see Additional file 1: Appendix S1). The titles and/or abstracts of the retrieved updated studies were screened in Endnote by the first author to identify randomized trials that met the inclusion criteria. Searches and selections were checked by a second author (NWJ). We selected all trials by applying the following inclusion criteria; where possible, criteria derived from Gøtzsche and Johansen [7] was applied.

- The study was published in the English language.

- The study was a peer-review publication with full text (no abstracts).

- The study was a randomized controlled trial with blinding.

- The control included a placebo or no treatment (by Gøtzsche and Johansen [7]).

- The participants were physician-diagnosed with bronchial allergic asthma. These included participants who underwent a mite sensitization assessment with either a skin test or serum assay for spe- cific IgE antibodies (by Gøtzsche and Johansen [7]). The asthma assessment included a history of asthma symptoms and a pulmonary function test.

- The intervention was designed to reduce the exposure to mite antigens in the home for the treatment of asthma (mono-trigger therapy by tertiary avoidance). This could include one of the following (by Gøtzsche and Johansen [7]):

a. Chemical (acaricides);

b. Physical (mattress covers, vacuum-cleaning, heating, ventilation, freezing, washing, air-filtration, and ionisers);

c. A combination of chemical and physical.

The flow chart of the updating search was made by use of the PRISMA diagram [22].

\section{Data extraction}

The data extraction was elaborated by the first author $(\mathrm{FvB})$; the extracted data included the study population, the type of intervention and control (the strategy of avoidance [13]), the study methodology (randomization and blinding), and outcomes. The outcomes included the main outcomes and the additional outcomes.

\section{Main outcomes}

- Mite allergen load from the mattress ( $\mu \mathrm{g} / \mathrm{g}$ dust).

- Asthma symptom score diaries (e.g. ASS/ACQ).

- Forced expiratory volume in $1 \mathrm{~s}$ percentage of predicted (\%) (FEV 1 \%pred.)

- Histamine or methacholine concentration that causes a $20 \%$ reduction in the $\mathrm{FEV}_{1}\left(\mathrm{PC}_{20}\right)$.

\section{Additional outcomes}

- Medication usage (use of inhaled corticosteroids: yes or no).

- Type of patient (child or adult).

- Presence of co-sensitization.

Missing data were requested from the study authors. A second author (NWJ) validated the selections and the data extraction by the first author. Any ambiguities in the selections and the extractions were resolved by discussion.

The mite allergen load in trials was measured by the allergen content, the number of mites or the guanine content. A rapid colorimetric test such as the Acarex ${ }^{\circledR}$ test can be used to measure the latter. Mite allergen exposure measured by Acarex ${ }^{\circledR}$ or an equivalent test was 
excluded from the analysis; the Acarex ${ }^{\circledR}$ test is poorly correlated with allergen content [23]. To estimate the allergen load from the number of mites in mattresses, the mean number of mites can be divided by a factor of 50 . This ratio is adapted from a nonsensitization threshold for allergens and for mites [24]. However, confidence limits for this calculation are unknown. We therefore also excluded mite counts. The most reliable way to measure the allergen content is with a chemical assay; the Enzyme-Linked Immuno Sorbent Assay (ELISA). In an ELISA the house dust mite allergens in the dust extract binds to an antibody, and are consequently linked to an enzyme, producing a detectable signal correlating to the antigen concentration in the extract [25]. This assay has been the most acceptable assay since 1989 [26]. We limited the studies to those measuring the mass ( $\mu \mathrm{g} / \mathrm{g}$ dust) of the mite allergen loads in mattresses with ELISA. Early epidemiologic studies defined a threshold level of $10.0 \mu \mathrm{g}$ mite allergen per gram of dust, above which asthmatic patients are in risk of asthma attacks [24]. Confidence boundaries were absent, reducing the threshold to a rule of thumb. Since then, there is a lack of papers on this threshold level, and thus never updated.

Questionnaires have been developed to measure asthma symptom scores and the adequacy of asthma control, regarding shortness of breath, wheeze, woken by asthma, severity of asthma in the morning, limiting activities because of asthma, use of a short-acting bronchodilator [27]. A limitation of the ASSs is that are no validated cut-off points indicating severity or level of control. In the validated questionnaire by Juniper, an ACQ of 1.50 (maximum 6) relates to inadequately controlled asthma, [28], corresponding to a standardized cut-point of 0.25 . The FEV $\mathrm{F}_{1}$ measures the obstruction in the airways during a forced expiratory flower using a spirometer [15]. An $\mathrm{FEV}_{1}$ \%pred. of 50 to $79 \%$ refers to moderate airflow obstruction, and $<50 \%$ to (very) severe obstruction [29]. In a standardized bronchoprovocation test, the dose histamine or methacholine is determined causing a $20 \%$ fall in $\mathrm{FEV}_{1}, \mathrm{PC}_{20}$ or $\mathrm{PD}_{20}$ [30]. A $\mathrm{PC}_{20}<1 \mathrm{mg} / \mathrm{mL}$ is considered a severe airway hyper responsiveness, and $>8 \mathrm{mg} /$ $\mathrm{mL}$ as being a normal responsiveness [31].

The analysis was limited to the main health outcomes with the most reported units. In the case of the ASS, we a priori standardized (SMN) the mean (MN) score by dividing it by the maximum number of the score (MAX). The variance was standardized in the same way $\left(\mathrm{SD}_{\text {standardized }}^{2}\right.$ $=\mathrm{SD}_{\text {extracted }}^{2} /\left(\mathrm{MAX}^{2 *}\right.$ number of patients $\left.)\right)$.

\section{Risk of bias assessment}

Gøtzsche and Johansen [7] judged the adequacy of the allocation concealment according to the Cochrane guidelines [32]. Their assessment was not included in the data synthesis. The trials selected for the updated analysis were assessed similarly for the risk of bias by the first author $(\mathrm{FvB})$ using the Cochrane checklist [32]. A second author (NWJ) validated the assessment by the first author. Any ambiguities in the assessed risk of bias were resolved by discussion. We also did not include the assessments in the data synthesis, as we did not hypothesize that the risk of bias or the quality of trials would affect the baseline characteristics.

\section{Statistical and sensitivity analyses}

The effect size was set as the mean for the physiological outcomes. The ASSs were standardized. First, the overall effect of the three health outcomes was estimated using a random-effects meta-analysis. Additionally, the $\mathrm{I}^{2}$ value was calculated to examine heterogeneity in the outcomes. A random-effect meta-regression and subgroups were introduced for all medical outcomes showing at least moderate heterogeneity. Covariates and subgroups of interest included the mite allergen load from the mattress at baseline and possible confounding by the use of inhaled corticosteroids, the type of patient (child/adult), and the presence of co-sensitization. Random-effects meta-regressions and subgroups were tested for a preferred minimum of ten trials [32]. Another sensitivity analysis yielded the exclusion of possible outliers as well as the results of the updated reference search. All calculations were performed with the Metafor 2.0.0 package in $R$ 3.5.3. [33, 34]. The level of significance was set to $\alpha=0.05$.

\section{Results}

Selection of references

The selection and inclusion of studies resulted in two groups of publications. The first group included the trials from the Gøtzsche and Johansen [7] analysis (fifty-five trials published until July 2011 [35-89]). We excluded twelve of these trials for being only abstracts, being published in a non-English language, not reporting data on the treatment of mite-allergic asthma, or containing non-usable data (outcomes not of prior interest; incomplete data) [35-45, 87]. One of the excluded trials was a large trial by Woodcock et al. [87], which dominated the meta-analysis by Gøtzsche and Johansen (weight $>40 \%$ ). Woodcock et al. [87] reported incomplete data in the subset of the mite load as well as the ASS. Further, the research team did not report the $\mathrm{FEV}_{1}$ or the $\mathrm{PC}_{20}$ data. The remaining forty-three trials were included for data extraction. The second group included studies identified in our updated search starting in July 2011 (Fig. 1). We found a total of 942 titles and abstracts. Nine hundred and fifteen titles were excluded for not reporting a randomized blinded trial on the effectiveness of tertiary mite 


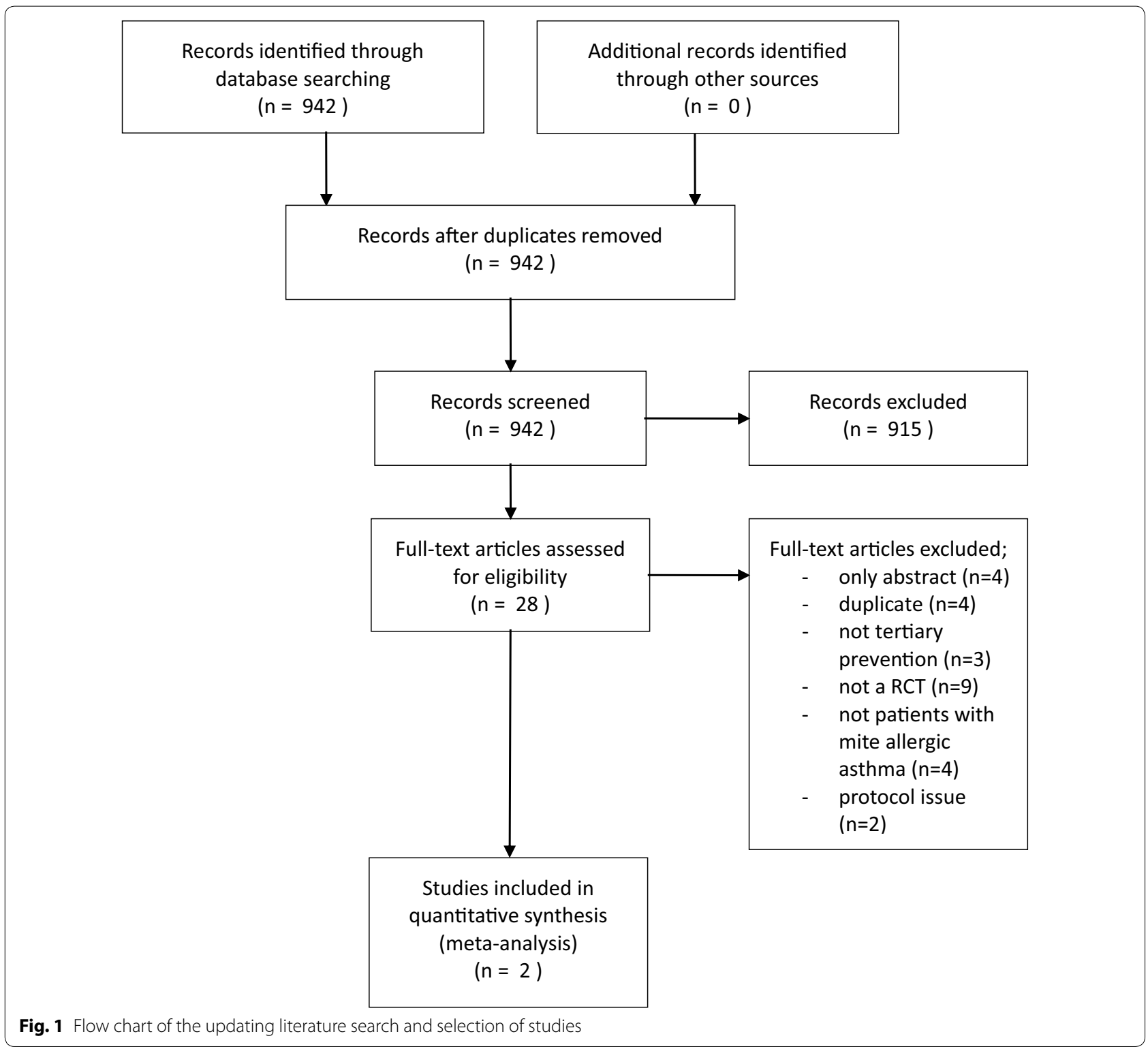

allergen avoidance. Twenty-eight potentially relevant titles were selected for inclusion [90-117]. Twenty-six full-text articles were excluded for not meeting our inclusion criteria (see Additional file 1: Appendix S1). Two full-text articles were included in the analysis [97, 115]. Finally, forty-five full-text articles were included in the analysis.

\section{Description of the included trials}

Thirty-nine trials reported avoidance using concurrent bedroom intervention strategies, and six trials reported air purification strategies. In twenty-five trials (56\%), patients used inhaled corticosteroids at baseline.
Twenty-one trials reported on the treatment of children with allergic asthma, the other twenty-four reported on the treatment of adults; some trials included both children and adults. In nineteen trials, co-sensitization at baseline was reported. Gøtzsche and Johansen [7] previously reported that eight of the included trials had a low risk of bias. Seven trials were judged to have a high risk of bias. The bias in the remaining twenty-eight trials was deemed unclear by Gøtzsche and Johansen [7]. We judged the trial by El-Ghitany and El-Salam [97] to have an unclear risk of bias (no information on concealment was included). The trial by Murray et al. [115] was judged to have a low risk of bias (use of a computerbased minimization procedure). 


\section{Mean characteristics at baseline}

Seventeen of the forty-five trials reported on the mite allergen load from the mattress at baseline, as measured by ELISA (mean $9.86 \mu \mathrm{g} / \mathrm{g}$ dust; 95\% CI 5.66 to $14.05 \mu \mathrm{g} / \mathrm{g}$ dust; range 0.44 to $24.83 \mu \mathrm{g} / \mathrm{g}$ dust; $\mathrm{n}=1066 ; \mathrm{I}^{2}=99.8 \%$; Fig. 2). The standardized ASSs at baseline were reported in twelve trials with high heterogeneity (standardized symptom score $=0.13 ; 95 \%$ CI 0.08 to 0.18 ; range: 0.03 to $0.29 ; n=703 ; I^{2}=99.9 \%$; Fig. 3). Sixteen studies reported the outcome $\mathrm{FEV}_{1}$ \%pred. by measuring the percentage predicted value $\left(\mathrm{FEV}_{1} \%\right.$ pred. $=85.3 \%$; $95 \% \mathrm{CI} 80.5$ to 90.1\%; range 68.5 to $102.2 \% ; \mathrm{n}=816 ; \mathrm{I}^{2}=95.8 \%$; Fig. 4 ). Fifteen trials reported $\mathrm{PC}_{20}$ values at baseline, expressed as $\mathrm{mg} / \mathrm{mL}$. The mean $\mathrm{PC}_{20}$ was $1.69 \mathrm{mg} / \mathrm{mL}$ (95\% CI 0.86 to $2.52 \mathrm{mg} / \mathrm{mL} ; \mathrm{n}=599 ; \mathrm{I}^{2}=95.6 \%$, Fig. 5).

\section{Dependence, subgroups and sensitivity analysis}

The covariate mite allergen load at baseline did not significantly influence the health outcomes (standardized
ASSs: $\mathrm{P}=0.13$; $\mathrm{FEV}_{1}$ \%pred.: $\mathrm{P}=0.81 ; \mathrm{PC}_{20}: \mathrm{P}=0.75$, see Additional file 1: Appendix S1). We calculated the $\mathrm{FEV}_{1}$ \%pred. in the adult subgroup ( $\mathrm{FEV}_{1}$ \%pred.; adults $=84.2 \%, 95 \%$ CI 79.2 to $89.2 \%$; 11 trials). All other subgroups included less than ten trials. Finally, the random-effects models for the health outcomes were unaltered when excluding the updated trials (symptom score 0.12; $\mathrm{FEV}_{1}$ \%pred.: $85.4 \%$; $\mathrm{PC}_{20}: 1.69 \mathrm{mg} / \mathrm{mL}$ ).

\section{Discussion}

This study contributes to the existing Cochrane review by Gøtzsche and Johansen [7] by generating hypotheses on the characteristics of asthma outcomes according to baseline data as well as possible dependencies for asthma outcomes. We observed considerable heterogeneity in the mite allergen load in the mattresses (17 trials), the standardized ASSs (12 trials), the $\mathrm{FEV}_{1}$ \%pred. values (16 trials), and the $\mathrm{PC}_{20}$ values (15 trials). We judged

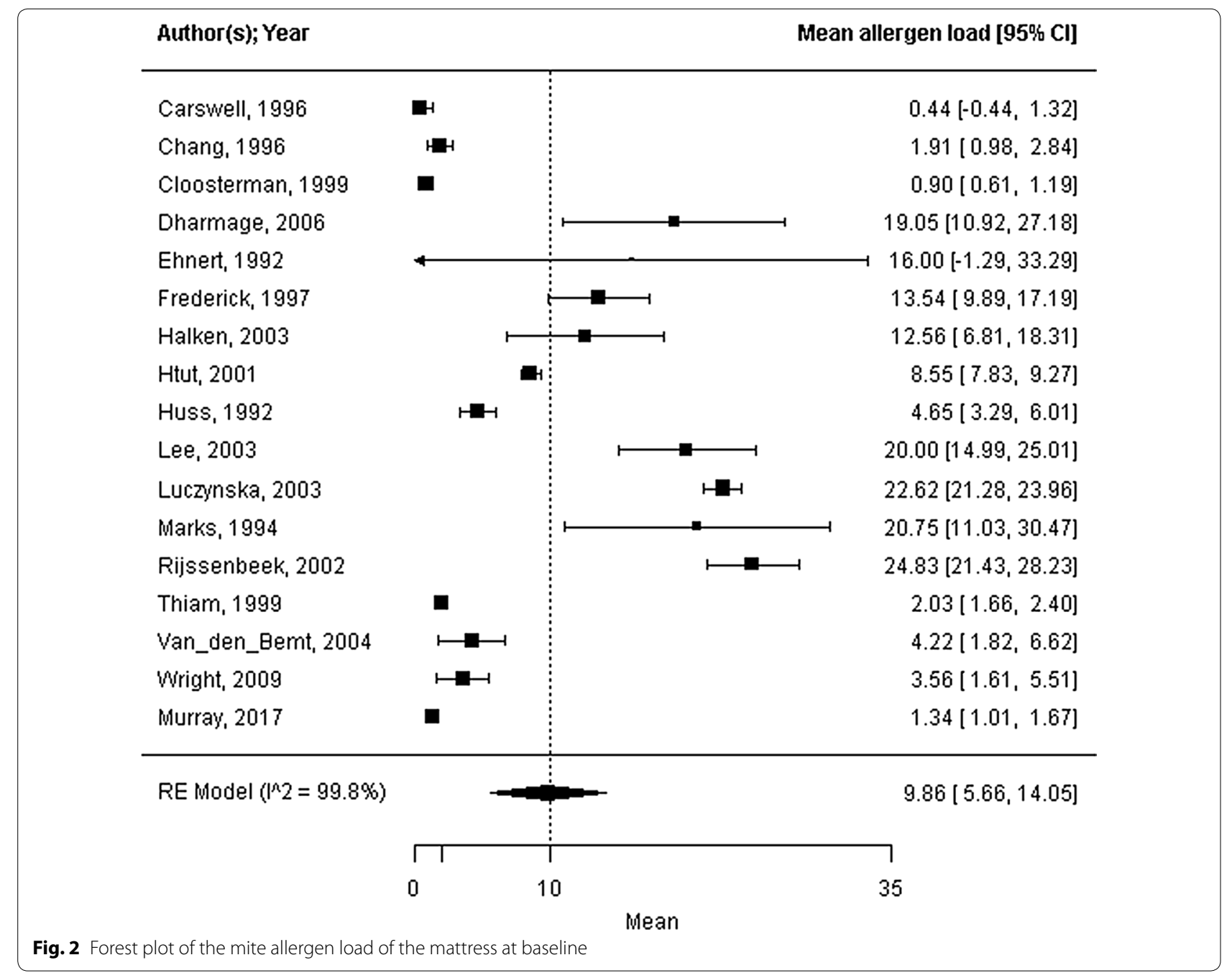




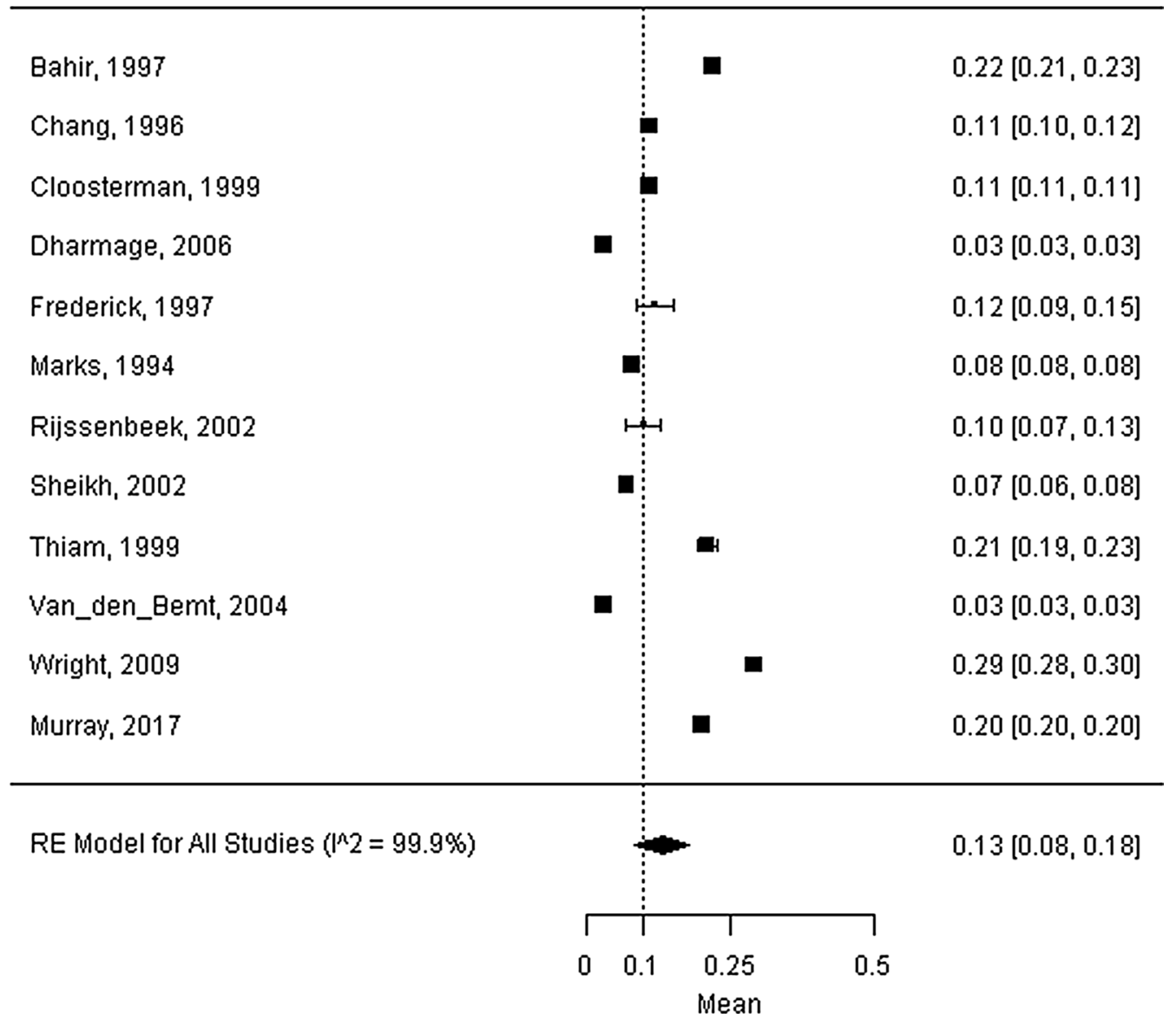

Fig. 3 Forest plot of the standardized asthma symptom scores at baseline

the mean mite allergen load from the mattress at baseline to be moderate $(9.86 \mu \mathrm{g} / \mathrm{g}$ dust $)$. Overall, the standardized ASSs and the percentage predicted $\mathrm{FEV}_{1}$ \%pred. suggested a mild to moderate disease. The $\mathrm{PC}_{20}$ at baseline predominantly indicated moderate to severe airway hyperresponsiveness according to the definition by Cockroft [31]. We did not observe a relationship between the mite allergen load from the mattress at baseline and health outcomes. The number of trials available did not allow for comparisons between the child and adult subgroups, the inhaled corticosteroid use or no use subgroups, or the presence or absence of co-sensitization subgroups.

In this study, we observed several factors related to the three attributes of prior interest. The first attribute was asthma severity. We observed a mild to moderate magnitude of asthma severity at baseline. We were, however, limited in our evaluation of asthma severity by the absence of appropriate instruments to assess asthma control $[27,118]$ and the asthma-related quality of life
[119]. Compatible with the situation of pharmacological treatments [16], it remains unknown whether the results found by Gøtzsche and Johansen [7] are generalizable to patients with uncontrolled asthma. In one trial [55], we extracted a median symptom score at daytime of zero for the treatment group. Since the score was already zero at baseline, it was probably clear that there would be no clinical benefit observed in this subset. The asthma outcomes showed more notable levels, such as a $\mathrm{FEV}_{1}$ \%pred. above $100 \%$, as reported by Carswell et al. [51]. The moderate asthma status at baseline was possibly related to the use of inhaled corticosteroids, as reported in more than half of the included trials (56\%). However, the number of trials available did not allow for testing this hypothesis.

A second attribute is the magnitude of the exposure at baseline, which relates to the environmental treatability. In four of the included trials [51-53, 115], we observed that the mean mite allergen load from the mattress at baseline was quite low (range 0.44 to $1.91 \mu \mathrm{g} / \mathrm{g}$ dust). Only one of these four trials included 


\section{Author(s); Year}

Mean FEV1 \%pred. [95\% Cl]

\begin{tabular}{|c|c|c|c|}
\hline Bahir, 1997 & $\mapsto$ & & $73.55[69.05,78.05]$ \\
\hline Carswell, 1996 & & $H$ & $102.22[99.73,104.71]$ \\
\hline Cloosterman, 1999 & & & $86.45[84.04,88.86]$ \\
\hline Dowward, 1988 & $\longmapsto$ & & $75.00[69.52,80.48]$ \\
\hline Marks, 1994 & & & $89.76[82.88,96.64]$ \\
\hline Popplewell, 2000 & & $\longrightarrow$ & $82.00[62.69,101.31]$ \\
\hline Reiser, 1990 & $\mapsto$ & & $80.00[75.67,84.33]$ \\
\hline Rijssenbeek, 2002 & & & $88.47[82.37,94.57]$ \\
\hline Thiam, 1999 & & $\rightarrow-$ & $98.85[86.53,111.17]$ \\
\hline Van_der_Heide, 1997 & & & $90.90[86.75,95.05]$ \\
\hline Van_der_Heide, 1997 & & & $94.00[80.44,107.56]$ \\
\hline Wiright, 2009 & H & & $83.20[79.99,86.41]$ \\
\hline El_Ghitany, 2012 & & & $84.74[83.87,85.61]$ \\
\hline \multirow[t]{4}{*}{ RE Model for All Studies $\left(\left.\right|^{\wedge} 2=95.8 \%\right)$} & & & $86.57[81.82,91.33]$ \\
\hline & $T$ & $T$ & 7 \\
\hline & 80 & 100 & 120 \\
\hline & & & \\
\hline
\end{tabular}

Fig. 4 Forest plot of the $\mathrm{FEV}_{1}$ percentage of predicted at baseline

an evaluation of the treatability of mite allergen exposure at baseline in their methods [52]. Environmentally, whether such low values of exposure are considered treatable remains a question. An exposure level of $0.44 \mu \mathrm{g} / \mathrm{g}$ dust is quite similar to the exposure level observed in the "low-allergen" region of Davos in the European Alps (approximately 0.02 to $0.2 \mu \mathrm{g} / \mathrm{g}$ dust; assessed from [120]). In addition, Pingitore and Pinter [121] noted that in many trials, there was no success in reducing the mite allergen load. Overall, it seems that multiple clinical trials on avoidance paid little attention to the environmental issue of the treatability of the exposure.

Furthermore, the attribute of dependence was of interest in this study. None of the medical baseline data could be related to mite allergen exposure from the mattress. This indicates that from a meta-viewpoint, at baseline, there was no clinical potential for reducing the mite allergen load in the bedding.
As far as we know, this is the first systematic review of baseline characteristics in trials on mite allergen avoidance for the treatment of asthma. This study was executed a priori to generate hypotheses for a new metaanalysis on the treatment of mite-allergic asthma by environmental control. Generating hypotheses to define a protocol for a meta-analysis prevents misleading conclusions [32]. We could not generate a hypothesis on a possible relationship with asthma outcomes, particularly considering the mite allergen exposure covariate. The mite allergen load from the mattress covariate was limited to the data obtained from ELISA. This limitation can be considered a rigorous selection factor to prevent bias in this covariate of prior interest. It is possible that some of the covariates we used were still unrefined. For instance, the covariate co-sensitization was introduced as a binary value (presence yes or no); we believe the next step is to introduce the number of co-sensitizations as an ordinal covariate. 
Author(s); Year

Mean PC20 [95\% $\mathrm{Cl}]$

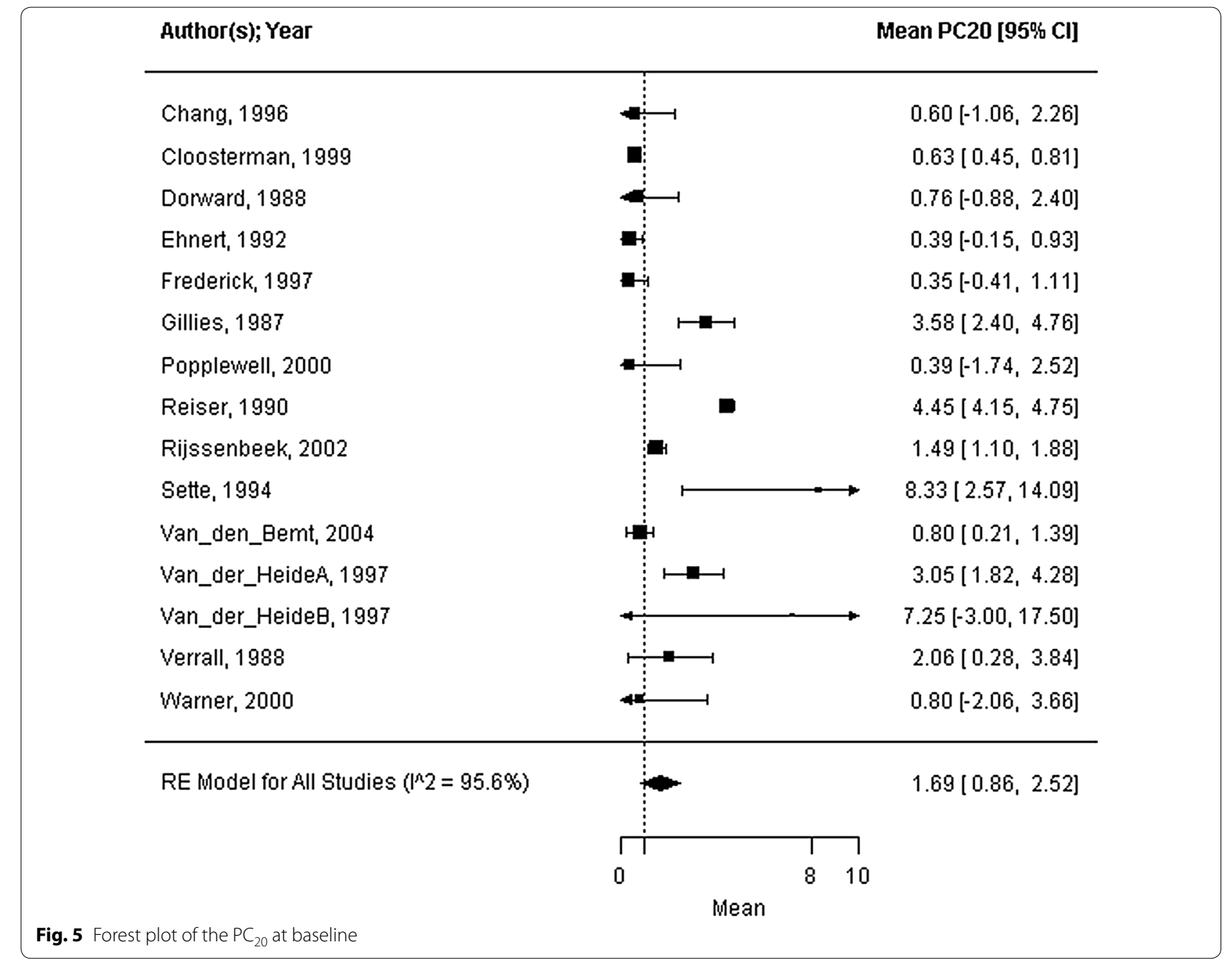

The main limitation of this study was that we had to exclude the large trial by Woodcock et al. [87] because their data was not usable data for the purpose of this study. Woodcock et al. did probably not include patients with uncontrolled asthma. Their publication included only adult patients with asthma who were undergoing routine management with inhaled corticosteroids in primary care. Though not a limitation, another large trial also worth noting is the recently published study by Murray et al. [115]. Murray et al. found that only the use of single covers prevented asthma exacerbations in the hospital setting. In a post hoc analysis, Murray et al. reported that relatively younger children $(P=0.006)$, those mono-sensitized to mites $(\mathrm{P}=0.04)$, those with severe asthma $(P=0.03)$, and those not exposed to smoking $(\mathrm{P}=0.02)$ explained the reduced number of hospital admissions in the 123 participants. No information was presented on the selection of significant covariates or on the power of the calculations. Possibly, the results by
Murray et al. [115] are explained by a more severe asthma status at baseline than those in the participants in the trials included by Gøtzsche and Johansen [7].

The baseline characteristics in a meta-analysis have been the subject of methodological studies, emphasizing the careful consideration of this topic in the definition of the protocol [21, 122]. Advanced statistical methods to evaluate underlying risk have been developed for cases in which the baseline characteristics or the severity of the disease among the participants varies [123]. The definition of the types of participants is considered a key factor in reviews [32]. A positive example of the explicit (a priori) consideration of baseline characteristics was demonstrated in the Cochrane review on the treatment of asthma by sublingual immunotherapy [124]. In contrast, the current meta-analyses on the treatment of asthma using avoidance were commonly characterized by no baseline characteristic reporting [7-11]. Gøtzsche and Johansen [7] stated that adjusting 
for baseline differences would risk biasing the review, "since investigators are inclined to show baseline differences and adjust for them when this procedure favours the experimental treatment". By limiting their meta-analysis to the changes and final values, Gøtzsche and Johansen [7] did not account for the types of participants they reviewed. Other Cochrane reviews on the treatment of asthma or rhinitis by mite allergen avoidance $[125,126]$, recognized for their rigorous methodology, do not account for the types of participants, as they did not describe their baseline characteristics. This suggests that there is room for improvement in the multiple Cochrane reviews and other meta-analyses on avoidance.

In conclusion, this systematic review demonstrates that many previous mite avoidance studies are characterized by the inclusion of patients with rather mild to moderate asthma and with varying and sometimes negligible levels of allergen exposure. Most likely, the use of asthma medication modified the baseline asthma outcomes in these studies, leaving less room to improve. In future studies, we suggest focusing on patients with partially controlled or uncontrolled asthma and assessing asthma control with the appropriate instruments $[27,118,119]$. Moreover, to test the efficacy of allergen avoidance, sufficient mite exposure at baseline should be present. In the absence of an evidence-based threshold level, we suggest the provisional use of the formerly defined rule of thumb that suggests that $10.0 \mu \mathrm{g}$ mite allergen per gram of dust is relevant to asthma symptoms [19].

\section{Supplementary information}

Supplementary information accompanies this paper at https://doi. org/10.1186/s13601-019-0306-3.

Additional file 1. Supplemental information on the keywords of the reference search; list of included and excluded studies in the updated search; the number of trials available per subgroup; figures of the health outcomes as a function of the allergen exposure.

\section{Acknowledgements}

The authors thank mister W.M. Bramer (MSc.) from Erasmus Medical Center for his assistance in the reference search. The protocol was registered at Prospero (number CRD42019119991).

\section{Authors' contributions \\ All authors contributed to the design of the work. FB and NWJ selected the references and extracted the data. FB and LRA analyzed the data. GJB and RGW contributed to the interpretation of the data. All authors contributed to the draft of the work. All authors read and approved the final manuscript.}

\section{Funding}

Not applicable.

\section{Availability of data and materials}

The datasets used and/or analysed during the current study are available from the corresponding author on reasonable request.
Ethics approval and consent to participate Not applicable.

\section{Consent for publication}

Not applicable.

\section{Competing interests}

The authors declare that they have no competing interests.

\section{Author details}

${ }^{1}$ Department of Internal Medicine, Section of Allergology \& Clinical Immunology, Erasmus Medical Center, P.O. Box 2040, 3000 CA Rotterdam, The Netherlands. ${ }^{2}$ Department of Pulmonology, Sint Franciscus Vlietland Groep, P.O. Box 10900, 3004 BA Rotterdam, The Netherlands. ${ }^{3}$ Department of Pulmonology, Erasmus Medical Center, Rotterdam, The Netherlands. ${ }^{4}$ Department of Biostatistics, Erasmus Medical Center, Rotterdam, The Netherlands. ${ }^{5}$ Department of Psychology, Education \& Child Studies, Erasmus University Rotterdam, P.O. Box 1738, 3000 DR Rotterdam, The Netherlands.

Received: 24 July 2019 Accepted: 13 December 2019

Published online: 06 January 2020

\section{References}

1. Backman H, Räisänen $P$, Hedman L, Stridsman C, Andersson M, Lindberg A, et al. Increased prevalence of allergic asthma from 1996 to 2006 and further to 2016-results from three population surveys. Clin Exp Allergy. 2017;47(11):1426-35.

2. Mincheva R, Ekerljung L, Bossios A, Lundbäck B, Lötvall J. High prevalence of severe asthma in a large random population study. J Allergy Clin Immunol. 2018;141(6):2256-63.

3. Miller JD. The Role of dust mites in allergy. Clin Rev Allergy Immunol. 2018. https://doi.org/10.1007/s12016-018-8693-0.

4. Custovic A, van Wijk RG. The effectiveness of measures to change the indoor environment in the treatment of allergic rhinitis and asthma: ARIA update (in collaboration with GA2LEN). Allergy. 2005;60:1112-5.

5. Dust-mite control measures of no use. Lancet. 2008;371(9622):1390.

6. Kader R, Kennedy K, Portnoy JM. Indoor environmental interventions and their effect on asthma outcomes. Curr Allergy Asthma Rep. 2018;18(3):17

7. Gøtzsche PC, Johansen HK. House dust mite control measures for asthma. Cochrane Database Syst Rev. 2008;2:CD001187.

8. Macdonald C, Sternberg A, Hunter PR. A systematic review and metaanalysis of interventions used to reduce exposure to house dust and their effect on the development and severity of asthma. Environ Health Perspect. 2007;115(12):1691.

9. Arroyave WD, Rabito FA, Carlson JC, Friedman EE, Stinebaugh SJ. Impermeable dust mite covers in the primary and tertiary prevention of allergic disease: a meta-analysis. Ann Allergy Asthma Immunol. 2014;112(3):237-48.

10. Singh M, Jaiswal N. Dehumidifiers for chronic asthma. Cochrane Database Syst Rev. 2013;6:CD003563.

11. Campbell F, Gibson PG. Feather versus non-feather bedding for asthma. Cochrane Database Syst Rev. 2000;4:CD002154.

12. van Boven FE. Effectiveness of mite-impermeable covers: a hypothesisgenerating meta-analysis. Clin Exp Allergy. 2014;44(12):1473-83.

13. van Boven FE, Arends LR, Braunstahl GJ, van Wijk RG. A reintroduction of environmental mite allergen control strategies for asthma treatment and the debate on their effectiveness. Clin Exp Allergy. 2019;49:400-9.

14. Wertli MM, Schöb M, Brunner F, Steurer J. Incomplete reporting of baseline characteristics in clinical trials: an analysis of randomized controlled trials and systematic reviews involving patients with chronic low back pain. PLoS ONE. 2013;8(3):e58512.

15. Global Initiative for Asthma. Pocket guide for asthma management and prevention; for adults and children older than 5 years. Updated 2018. www.ginasthma.org.

16. Brown T, Jones T, Gove K, Barber C, Elliott S, Chauhan A, Howarth P. Randomised controlled trials in severe asthma: selection by 
phenotype or stereotype. Eur Respir J. 2018;52:1801444. https://doi. org/10.1183/13993003.01444-2018.

17. McDonald VM, Hiles SA, Godbout K, Harvey ES, Marks GB, Hew M, et al. Treatable traits can be identified in a severe asthma registry and predict future exacerbations. Respirology. 2019;24(1):37-47.

18. Bronswijk van JEMH. Prevention and extermination strategies for house dust mites and their allergens in home textiles. In: Proceedings of the first international conference of insect pests in the urban environment, Exeter, United Kingdom: BPCC Wheatons Ltd.; 1993. p. 261-6.

19. Platts-Mills TA, Thomas WR, Aalberse RC, Vervloet D, Champman MD. Dust mite allergens and asthma: report of a second international workshop. J Allergy Clin Immunol. 1992;89(5):1046-60.

20. Becker BJ, Wu MJ. The synthesis of regression slopes in meta-analysis. Stat Sci. 2007:22(3):414-29.

21. Chaimani A. Accounting for baseline differences in meta-analysis. Evid Based Ment Health. 2015;18(1):23-6.

22. Moher D, Liberati A, Tetzlaff J, Altman DG, The PRISMA Group. Preferred reporting items for systematic reviews and meta-analyses: the PRISMA statement. PLoS Med. 2009;6(7):e1000097.

23. Haouichat H, Pauli G, Ott M, Hedelin G, de Blay F, Verot A, Bessot JC. Controlling indoor mite exposure: the relevance of the Acarex test. Indoor Built Environ. 2001;10(2):109-15.

24. Platts-Mills TA, de Weck AL, Aalberse RC, Bessot JC, Bjorksten B, Bischoff

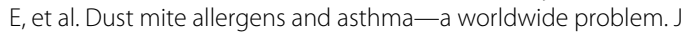
Allergy Clin Immunol. 1989;83(2):416-27.

25. Engvall E, Perlmann P. Enzyme-linked immunosorbent assay, ELISA: III. Quantitation of specific antibodies by enzyme-labeled anti-immunoglobulin in antigen-coated tubes. J Immunol. 1972;109(1):129-35.

26. Luczynska CM, Arruda LK, Platts-Mills TA, Miller JD, Lopez M, Chapman MD. A two-site monoclonal antibody ELISA for the quantification of the major Dermatophagoides spp. allergens, Der p I and Der f I. J Immunol Methods. 1989;1 18(2):227-35.

27. Juniper EF, O'byrne PM, Guyatt GH, Ferrie PJ, King DR. Development and validation of a questionnaire to measure asthma control. Eur Respir J. 1999;14(4):902-7.

28. Juniper EF, Bousquet J, Abetz L, Bateman ED, Goal Committee. Identifying 'well-controlled'and 'not well-controlled'asthma using the Asthma Control Questionnaire. Respir Med. 2006;100(4):616-21.

29. Moore VC. Spirometry: step by step. Breathe. 2012;8(3):232-40.

30. Sterk PJ. Airway hyperresponsiveness: using bronchial challenge tests in research and management of asthma. J Aerosol Med. 2002;15(2):123-9.

31. Cockcroft DW, Murdock KY, Berscheid BA, Gore BP. Sensitivity and specificity of histamine $\mathrm{PC}_{20}$ determination in a random selection of young college students. J Allergy Clin Immunol. 1992;89(1):23-30.

32. Higgins JP, Green S. Cochrane handbook for systematic reviews of interventions. Hoboken: Wiley-Blackwell; 2008.

33. Viechtbauer W. Conducting meta-analyses in R with the metafor package. J Stat Softw. 2010;36(3):1-48.

34. Ihaka R, Gentleman R. R: a language for data analysis and graphics. J Comput Graph Stat. 1996;5(3):299-314.

35. Charpin D, Birnbaum J, Haddi E, N'Guyen A, Fondarai J, Vervloet D. Evaluation de l'efficacité d' un acaricide, Acardust, dans le traitement de I'allergie aux acariens. Rev Fr d'Allergol. 1990;30:149-55.

36. Chen CC, Hsieh K-H. Effects of Microstop-treated antimite bedding on children with mite-sensitive asthma. Acta Paediatr Sin. 1996;37:420-7.

37. Cinti C, Canessa PA, Lavecchia MA, Capecchi V. Efficacia di un coprimaterasso e copricuscino'antiacaro' nel controllo dell'asma dei pazienti allergici al dermatophagoides. Lotta Contro La Tuberculosi e Le Malattie Polmonari Sociali. 1996;66:131-8.

38. Fang $Z$, Cai $Y$, Wang L. The efficacy of controlling of house dusts in attacks of mite sensitive asthmatics. Zhonghua Jie He He Hu Xi Za Zhi. 2001;24(11):685-9.

39. Geller-Bernstein C, Pibourdin JM, Dornelas A, Fondarai J. Efficacy of the acaricide: acardust for the prevention of asthma and rhinitis due to dust mite allergy, in children. Allergie et Immunol. 1995;27:147-54.

40. Ghazala L, Schmid F, Helbling A, Pichler WJ, Pichler CE. Efficacy of house dust mite- and allergen-impermeable encasings in patients with house dust mite allergy. Allergologie. 2004;27(1):26-34.

41. Howarth P, Lunn A, Tomkin S. Bedding barrier intervention in house dust mite respiratory allergy. Clin Exp Allergy. 1992;22:140.
42. Maesen FPV, Sluysmans FG, Brombacher PJ, Smeets JJ. Ervaringen met het gebruik van luchtfiltratieapparatuur in de woonruimten van voor huisstof overgevoelige atopische patienten. Acta Tuberculosea et Pneumologica Belgica. 1977;68:133-47.

43. Matthys $\mathrm{H}$, Hupert A, Busch B. Dry air in bedrooms of patients with house dust mite-induced asthma. Eur Respir J. 1996;9(Suppl 23):350s, abstract P2175.

44. Sooltangos S, Khodaboccus F, Baligadoo S, Leynadier F, Fadel R. Effect of house dust mites (HDM) avoidance measures on symptoms of asthmatic patients in Island of Mauritius. J Allergy Clin Immunol. 1992:89:259.

45. Van der Heide $S$, van Aalderen WM, Kauffman HF, Dubois AE, de Monchy JG. Clinical effects of air cleaners in homes of asthmatic children sensitized to pet allergens. J Allergy Clin Immunol. 1999;104(2 Pt 1):447-51.

46. Antonicelli L, Bilo MB, Pucci S, Schou C, Bonifazi F. Efficacy of an aircleaning device equipped with a high efficiency particulate air filter in house dust mite respiratory allergy. Allergy. 1991;46:594-600.

47. Bahir A, Goldberg A, Mekori YA, Confino Cohen R, Morag H, Rosen Y, et al. Continuous avoidance measures with or without acaricide in dust mite-allergic asthmatic children. Ann Allergy Asthma Immunol. 1997;78(5):506-12.

48. Burr ML, St Leger AS, Neale E. Anti-mite measurements in mite-sensitive adult asthma. A controlled trial. Lancet. 1976;1:333-5.

49. Burr ML, Dean BV, Merrett TG, Neale E, St Leger AS, Verrier-Jones ER. Effects of anti-mite measures on children with mite-sensitive asthma: a controlled trial. Thorax. 1980:35:506-12.

50. Burr ML, Neale E, Dean BV, Verrier-Jones ER. Effect of a change to mitefree bedding on children with mite-sensitive asthma: a controlled trial. Thorax. 1980;35:513-4.

51. Carswell F, Birmingham K, Oliver J, Crewes A, Weeks J. The respiratory effects of reduction of mite allergen in the bedrooms of asthmatic children — a double-blind controlled trial. Clin Exp Allergy. 1996;26:386-96.

52. Chang H, Becker A, Ferguson A, Manfreda J, Simons E, Chan H, et al. Effect of application of benzyl benzoate on house dust mite allergen levels. Ann Allergy Asthma Immunol. 1996;77(3):187-90.

53. Cloosterman SG, Schermer TR, Bijl Hofland ID, Van Der Heide S, Brunekreef B, Van Den Elshout FJ, et al. Effects of house dust mite avoidance measures on Der $p 1$ concentrations and clinical condition of mild adult house dust mite-allergic asthmatic patients, using no inhaled steroids. Clin Exp Allergy. 1999;29(10):1336-46.

54. de Vries MP, van den Bemt L, Aretz K, Thoonen BP, Muris JW, Kester $A D$, et al. House dust mite allergen avoidance and self-management in allergic patients with asthma: randomised controlled trial. $\mathrm{Br} J \mathrm{Gen}$ Pract. 2007;57(536):184-90.

55. Dharmage S, Walters EH, Thien F, Bailey M, Raven J, Wharton C, et al. Encasement of bedding does not improve asthma in atopic adult asthmatics. Int Arch Allergy Immunol. 2006;139(2):132-8.

56. Dietemann A, Bessot JC, Hoyet C, Ott M, Verot A, Pauli G. A doubleblind, placebo controlled trial of solidified benzyl benzoate applied in dwellings of asthmatic patients sensitive to mites: clinical efficacy and effect on mite allergens. J Allergy Clin Immunol. 1993;91:738-46.

57. Dorward AJ, Colloff MJ, MacKay NS, McSharry C, Thomson NC. Effect of house dust mite avoidance measures on adult atopic asthma. Thorax. 1988:43:98-102.

58. Ehnert B, Lau-Schadendorf S, Weber A, Buettner P, Schou C, Wahn U. Reducing domestic exposure to dust mite allergen reduces bronchial hyperreactivity in sensitive children with asthma. J Allergy Clin Immunol. 1992;90:135-8.

59. Frederick JM, Warner JO, Jessop WJ, Enander I, Warner JA. Effect of a bed covering system in children with asthma and house dust mite hypersensitivity. Eur Respir J. 1997;10(2):361-6.

60. Gillies DRN, Littlewood JM, Sarsfield JK. Controlled trial of house dust mite avoidance in children with mild to moderate asthma. Clin Allergy Immunol. 1987;17:105-11.

61. Halken S, Host A, Niklassen U, Hansen LG, Nielsen F, Pedersen S, et al. Effect of mattress and pillow encasings on children with asthma and house dust mite allergy. J Allergy Clin Immunol. 2003;111(1):169-76.

62. Htut T, Higenbottam TW, Gill GW, Darwin R, Anderson PB, Syed N. Eradication of house dust mite from homes of atopic asthmatic subjects: a double-blind trial. J Allergy Clin Immunol. 2001;107(1):55-60. 
63. Huss K, Squire EN, Carpenter GB, Smith LJ, Huss RW, Salata K, et al. Effective education of adults with asthma who are allergic to dust mites. J Allergy Clin Immunol. 1992;89:836-43.

64. Jooma OF, Weinberg EG, Berman D, Manjra Al, Potter PC. Accumulation of house-dust mite (Der-p-1) levels on mattress covers. South Afr Med J. 1995;85(10):1002-5.

65. Korsgaard J. Preventive measures in mite asthma. A controlled trial. Allergy. 1983;38:93-102.

66. Kroidl RF, Gobel D, Balzer D, Trendelenburg F, Schwichtenberg U. Clinical effects of benzyl benzoate in the prevention of house-dustmite allergy. Results of a prospective, double-blind, multicenter study. Allergy. 1998;53(4):435-40.

67. Lee IS. Effect of bedding control on amount of house dust mite allergens, asthma symptoms, and peak expiratory flow rate. Yonsei Med J. 2003;44(2):313-22.

68. Luczynska C, Tredwell E, Smeeton N, Burney P. A randomized controlled trial of mite allergen-impermeable bed covers in adult mite-sensitized asthmatics. Clin Exp Allergy. 2003;33:1648-53.

69. Manjra A, Berman D, Toerien A, Weinberg EG, Potter PC. The effects of a single treatment of an acaricide, Acarosan, and a detergent, Metsan, on Der $p 1$ allergen levels in the carpets and mattresses of asthmatic children. South Afr Med J. 1994;84:278-80.

70. Marks GB, Tovey ER, Green W, Shearer M, Salome CM, Woolcock AJ. House dust mite allergen avoidance: a randomized controlled trial of surface chemical treatment and encasement of bedding. Clin Exp Allergy. 1994;24:1078-83.

71. Mitchell EA, Elliott RB. Controlled trial of an electrostatic precipitator in childhood asthma. Lancet. 1980;2:559-61.

72. Popplewell EJ, Innes VA, Lloyd-Hughes S, Jenkins EL, Khdir K, Bryant TN, et al. The effect of high-efficiency and standard vacuum-cleaners on mite, cat and dog allergen levels and clinical progress. Pediatr Allergy Immunol. 2000;11(3):142-8.

73. Reiser J, Ingram D, Mitchell EB, Warner JO. House dust mite allergen levels and an anti-mite mattress spray (natamycin) in the treatment of childhood asthma. Clin Exp Allergy. 1990;20:561-7.

74. Rijssenbeek-Nouwens LH, Oosting AJ, de Bruin-Weller MS, Bregman I, de Monchy JG, Postma DS. Clinical evaluation of the effect of antiallergic mattress covers in patients with moderate to severe asthma and house dust mite allergy: a randomised double blind placebo controlled study. Thorax. 2002;57(9):784-90.

75. Sette L, Comis A, Marcucci F, Sensi L, Piacentini GL, Boner AL. Benzylbensoate foam: effects on mite allergens in mattress, serum and nasal secretory IgE to dermatophagoides pteronyssinus, and bronchial hyperreactivity in children with allergic asthma. Pediatr Pulmonol. 1994;18:218-27.

76. Shapiro GG, Wighton TG, Chinn T, Zuckrman J, Eliassen AH, Picciano JF, et al. House dust mite avoidance for children with asthma in homes of low-income families. J Allergy Clin Immunol. 1999;103(6):1069-74.

77. Sheikh A, Hurwitz B, Sibbald B, Barnes G, Howe M, Durham S. House dust mite barrier bedding for childhood asthma: randomised placebo controlled trial in primary care. BMC Fam Pract. 2002;3(1):12.

78. Thiam DG, Tim CF, Hoon LS, Lei Z, Bee-Wah L. An evaluation of mattress encasings and high efficiency particulate filters on asthma control in the tropics. Asian Pac J Allergy Immunol. 1999;17:169-74.

79. Van den Bemt L, Van Knapen L, De Vries MP, Jansen M, Cloosterman S, Van Schayck CP. Clinical effectiveness of a mite allergen-impermeable bed-covering system in asthmatic mite-sensitive patients. J Allergy Clin Immunol. 2004;114(4):858-62.

80. Van der Heide S, Kaufmann HF, Dubois AEJ, de Monchy JGR. Allergenavoidance measures in homes of house-dustmite- allergic asthmatic patients: effects of acaricides and mattress encasings. Allergy. 1997:52:921-7.

81. Van der Heide S, Kauffman HF, Dubois AE, de Monchy JG. Allergen reduction measures in houses of allergic asthmatic patients: effects of air-cleaners and allergen-impermeable mattress covers. Eur Respir J. 1997:10(6):1217-23.

82. Verrall B, Muir DC, Wilson WM, Milner R, Johnston M, Dolovitch J. Laminar flow air cleaner bed attachment: a controlled trial. Ann Allergy. 1988;61:117-22

83. Walshaw MJ, Evans CC. Allergen avoidance in house dust mite sensitive adult asthma. Q J Med. 1986;58:199-215.
84. Warburton CJ, Niven RMCL, Pickering CA, Fletcher AM, Hepworth J, Francis HC. Domiciliary air filtration units, symptoms and lung function in atopic asthmatics. Respir Med. 1994;88:771-6.

85. Warner JA, Marchant JL, Warner JO. Double blind trial of ionisers in children with asthma sensitive to the house dust mite. Thorax. 1993;48:330-3.

86. Warner JA, Frederick JM, Bryant TN, Weich C, Raw GJ, Hunter C, et al. Mechanical ventilation and high-efficiency vacuum cleaning: a combined strategy of mite and mite allergen reduction in the control of mite-sensitive asthma. J Allergy Clin Immunol. 2000;105(1 Pt 1):75-82.

87. Woodcock A, Forster L, Matthews E, Martin J, Letley L, Vickers M, et al. Control of exposure to mite allergen and allergen-impermeable bed covers for adults with asthma. N Eng J Med. 2003;349(3):225-36.

88. Wright GR, Howieson S, McSharry C, McMahon AD, Chaudhuri R, Thompson J, et al. Effect of improved home ventilation on asthma control and house dust mite allergen levels. Allergy. 2009;64:1671-80.

89. Zwemer RJ, Karibo J. Use of laminar control device as adjunct to standard environmental control measures in symptomatic asthmatic children. Ann Allergy. 1973;31:284-90.

90. Breysse J, Wendt J, Dixon S, Murphy A, Wilson J, Meurer J, et al. Nurse case management and housing interventions reduce allergen exposures: the Milwaukee randomized controlled trial. Public Health Rep. 2011;126(SUPPL. 1):89-99.

91. Eick SA, Richardson G. Investigation of different approaches to reduce allergens in asthmatic children's homes-The Breath of Fresh Air Project, Cornwall, United Kingdom. Sci Total Environ. 2011;409(19):3628-33.

92. Glasgow NJ, Ponsonby AL, Kemp A, Tovey E, Van Asperen P, McKay K, et al. Feather bedding and childhood asthma associated with house dust mite sensitisation: a randomised controlled trial. Arch Dis Child. 2011;96(6):541-7.

93. Maas T, Dompeling E, Muris JWM, Wesseling G, Knottnerus JA, van Schayck OCP. Prevention of asthma in genetically susceptible children: a multifaceted intervention trial focussed on feasibility in general practice. Pediatr Allergy Immunol. 2011;22(8):794-802.

94. Neumayr A, Niebauer E, Weber N, Haussinger K. Reduction of house dust mite allergens by using a silver-doped sleeping system. Allergologie. 2011;34(5):248-57.

95. Takaro TK, Krieger J, Song L, Sharify D, Beaudet N. The Breathe-Easy Home: the impact of asthma-friendly home construction on clinical outcomes and trigger exposure. Am J Public Health. 2011;101(1):55-62.

96. Celano MP, Holsey CN, Kobrynski LJ. Home-based family intervention for low-income children with asthma: a randomized controlled pilot study. J Fam Psychol. 2012;26(2):171-8.

97. El-Ghitany EM, El-Salam MMA. Environmental intervention for house dust mite control in childhood bronchial asthma. Environ Health Prev Med. 2012:17(5):377-84.

98. Gehring U, De Jongste JC, Kerkhof M, Oldewening M, Postma D, Van Strien RT, et al. The 8-year follow-up of the PIAMA intervention study assessing the effect of mite-impermeable mattress covers. Allergy. 2012;67(2):248-56.

99. Ho A, Vosicka K, Gore RB, Svensson P, Warner JO, Boyle RJ. Effect of temperature-controlled laminar airflow on symptoms and sleep quality in perennial allergic rhinitis. Clin Exp Allergy. 2012:42(12):1839-40.

100. Scott M, Roberts G, Kurukulaaratchy RJ, Matthews S, Nove A, Arshad SH. Multifaceted allergen avoidance during infancy reduces asthma during childhood with the effect persisting until age 18 years. Thorax. 2012;67(12):1046-51.

101. Yunus F, Sutoyo DK. The effect of air filter with balanced anion-cation usage on airway inflammation, asthma control, and lung function test of allergic asthma patients. Respirology. 2012;17:6.

102. NCT. Cross-over study of the impact of Purotex covers on the concentration of house dust mite allergen in bedding and the quality of life in patients with allergic rhinitis to house dust mite. Clinicaltrialsgov[http:// www.clinicaltrials.gov]. 2013.

103. Tsurikisawa N, Saito A, Oshikata C, Nakazawa T, Yasueda H, Akiyama K. Encasing bedding in covers made of microfine fibers reduces exposure to house mite allergens and improves disease management in adult atopic asthmatics. Allergy Asthma Clin Immunol. 2013;9(1):44.

104. Hogaard NV. P79-AsthmaVent-effect of mechanical ventilation on asthmacontrol in house dust mite allergic children with asthma. Clin Transl Allergy. 2014;4:132 
105. NCT. AsthmaVent - effect of mechanical ventilation on asthma control in children. https://www.clinicaltrialsgov/show/nct02068573. 2014.

106. Hogaard NV. AsthmaVent - effect of mechanical ventilation on asthmacontrol in house dust mite allergic children with asthma. Clin Transl Allergy. 2014;4(Suppl 1):42[P134].

107. Murray CS, Sumner H, Mycock M, Duxbury A, Custovic A, Simpson A. Preventing asthma exacerbations by allergen-impermeable bed covers in children: double-blind randomised placebo controlled trial. Allergy. 2015;70:75.

108. Smith H, Horney D, Goubet S, Jones C, Raza A, White P, et al. Pragmatic randomized controlled trial of a structured allergy intervention for adults with asthma and rhinitis in general practice. Allergy. 2015;70(2):203-11.

109. Sumner $H$, Begum $H$, Simpson A, Custovic A, Murray CS. The practicalities of using allergen impermeable bed covers in children with mite allergic asthma. Thorax. 2015;70:A122.

110. DiMango E, Serebrisky D, Narula S, Shim C, Keating C, Sheares B, et al. Individualized household allergen intervention lowers allergen level but not asthma medication use: a randomized controlled trial. J Allergy Clin Immunol Pract. 2016:4(4):671.e4-679.e4.

111. NCT. Impact of reduction of dust mite allergenic load on step down of inhaled corticosteroids in stable asthma. https://www.clinicaltrialsgov/ show/nct02773628. 2016.

112. Tsurikisawa N, Saito A, Oshikata C, Yasueda H, Akiyama K. Effective allergen avoidance for reducing exposure to house dust mite allergens and improving disease management in adult atopic asthmatics. J Asthma. 2016;53(8):843-53.

113. Winn AK, Salo PM, Klein C, Sever ML, Harris SF, Johndrow D, et al. Efficacy of an in-home test kit in reducing dust mite allergen levels: results of a randomized controlled pilot study. J Asthma. 2016;53(2):133-8.

114. Luo J, Chen Z, Sun B. Efficacy of air purifier therapy in allergic asthma. Respirology. 2017;22(Supplement 3):97.

115. Murray CS, Foden P, Sumner H, Shepley E, Custovic A, Simpson A. Preventing severe asthma exacerbations in children a randomized trial of mite-impermeable bedcovers. Am J Respir Crit Care Med. 2017:196(2):150-8.
116. Morten M, Collison A, Murphy VE, Barker D, Oldmeadow C, Attia J, et al. Managing asthma in pregnancy (MAP) trial: FENO levels and childhood asthma. J Allergy Clin Immunol. 2018;142(6):1765.e4-1772.e4.

117. Bjermer L, Eriksson G, Radner F, Peterson S, Warner JO. Time to onset of improvements in quality of life from temperature-controlled laminar airflow (TLA) in severe allergic asthma. Respir Med. 2019;147:19-25.

118. Nathan RA, Sorkness CA, Kosinski M, Schatz M, Li JT, Marcus P, et al. Development of the asthma control test: a survey for assessing asthma control. J Allergy Clin Immunol. 2004;113(1):59-65.

119. Juniper EF, Guyatt GH, Epstein RS, Ferrie PJ, Jaeschke R, Hiller TK. Evaluation of impairment of health related quality of life in asthma: development of a questionnaire for use in clinical trials. Thorax. 1992:47(2):76-83.

120. Spieksma FTM, Zuidema P, Leupen MJ. High altitude and house-dust mites. Br Med J. 1971;1(5740):82-4

121. Pingitore G, Pinter E. Environmental interventions for mite-induced asthma: a journey between systematic reviews, contrasting evidence and clinical practice. Eur Ann Allergy Clin Immunol. 2013:45(3):74-7.

122. Riley RD, Lambert PC, Abo-Zaid G. Meta-analysis of individual participant data: rationale, conduct, and reporting. BMJ. 2010:340:c221.

123. Arends LR, Hoes AW, Lubsen J, et al. Baseline risk as predictor of treatment benefit: three clinical meta-re-analyses. Stat Med. 2000;19:3497-518.

124. Normansell R, Kew KM, Bridgman AL. Sublingual immunotherapy for asthma. Cochrane Database Syst Rev. 2015;8:CD011293.

125. Kilburn SA, Lasserson TJ, McKean MC. Pet allergen control measures for allergic asthma in children and adults. Cochrane Database Syst Rev. 2001;1:CD002989

126. Sheikh A, Hurwitz B, Nurmatov U, van Schayck CP. House dust mite avoidance measures for perennial allergic rhinitis. Cochrane Database Syst Rev. 2010;7:001563.

\section{Publisher's Note}

Springer Nature remains neutral with regard to jurisdictional claims in published maps and institutional affiliations.
Ready to submit your research? Choose BMC and benefit from:

- fast, convenient online submission

- thorough peer review by experienced researchers in your field

- rapid publication on acceptance

- support for research data, including large and complex data types

- gold Open Access which fosters wider collaboration and increased citations

- maximum visibility for your research: over $100 \mathrm{M}$ website views per year

At BMC, research is always in progress.

Learn more biomedcentral.com/submissions 